\title{
STATUS OF UNDERGRADUATE COMMUNITY-BASED AND PUBLIC HEALTH PHYSIOTHERAPY EDUCATION IN SOUTH AFRICA
}

\begin{abstract}
Curricula of health education institutions need to be periodically revised to be aligned with its context. This study explored the status of physiotherapy curricula in South Africa as point of departure for benchmarking by individual institutions.

A document analysis was done of the university physiotherapy departments $(N=8)$ in South Africa. Institutional ethical clearance and permission from the heads of departments were obtained. Content analysis was used to analyse the South African Qualifications Authority exit-level outcomes and the university study guides for community placements.

Most universities employed a form of service-learning, with interventions in a range of settings. Five themes emerged: practice of evidence-based physiotherapy, rendering physiotherapy services, acting professionally, communication, and collaboration. The country's priority conditions were addressed. Teaching-learning strategies included group activities (class or education sessions), community projects, home visits and portfolios of evidence. Personal and small-group reflections were prominent.

The undergraduate community physiotherapy curricula in South Africa address the health profile of the population and priorities in the health system to different degrees. The variation between universities should be interpreted with caution as the study guides only gave a limited snapshot into each institution's curriculum. However, findings suggest that each physiotherapy university department may have gaps in preparing physiotherapy undergraduate students for the needs of the South African population and expectations of the Government. Possible ways to share teaching-learning resources are recommended.
\end{abstract}

KEY WORDS: EDUCATION, COMMUNITY, PUBLIC HEALTH, SERVICE LEARNING, DOCUMENT ANALYSIS.

\section{INTRODUCTION}

All South African (SA) medical schools have undertaken major curriculum reform over the past 20 years (Burch 2007). However, published literature describing transformational curriculum changes and their educational impact is limited (Burch 2007). Information on publications regarding physiotherapy curricula is also scarce. Internationally two efforts towards physiotherapy curriculum frameworks were found; one

\section{Correspondence Author:}

Karien Mostert-Wentzel

PO Box 223, Newlands,

Pretoria, 0049

South Africa

Email: karien.mostert@up.ac.za developed in Europe (Broberg et al 2003) and the other in Canada (Darrah et al 2006). Broberg et al (2003) organised their framework along three aspects: content, student learning and the socio-cultural context. Darrah et al. (2006) developed the CORE (clientorientated research and evaluation) Model of Best Practice and Clinical Decision-making around four principles which are the integration of theory, clinical practice and research; clientorientation and concepts from the International Classification of Functioning, Disability and Health (ICF). Both of these models, although they incorporate contextual factors, have a clinical perspective that does not embrace public health or community development - two core issues relevant to the local context.
Similarly, Stainsby and Bannigan (2011) identified skills for physiotherapy students working in community settings in the United Kingdom. The four skills sets - communication, function, assessment and treatment, coping in an uncontrolled environment and prioritisation - was limited to physiotherapy in home settings. Ramklass (2009a) asserts that in SA, physiotherapy education has "remained relatively static" since 1994 . Education at one university investigated still did physiotherapy clinical training mainly in urban and institutionalised settings (Ramklass 2009b). The author also identified gaps in knowledge and skills around practice in resource-poor settings, language and cultural barriers, social responsibility, empathy, interpersonal relationships and administra- 
tion. Innovation at two other universities, however, did describe clinical learning in community settings (Futter 2003). Although in the one study students worked mainly at clinics during their service-learning placement and did domiciliary visits with community workers (Krause 2007). In comparison, the community-based placements addressed wider public health elements, such as the cultural determinants of health (Futter 2003).

The first step when reviewing curricula is to revisit the "problem" that the curriculum needs to address in terms of the health profile and policies of the country (Kern et al 2009). Owing to the dynamic nature of the health sector, curricula for the education of healthcare practitioners, including physiotherapists, need to be periodically reviewed for relevance and quality (Davenport et al 2009).

\section{South African health policy envi- ronment}

The health sector is a key player in the South African Government's strategy to fight poverty, discrimination and to build the nation (Democracy and Governance Human Science Research Council (HSRC) 2005) The vision for the health sector is "A Long and Healthy Life for All South Africans" (Department of Health 2009). The National Department of Health specifically agreed to improve life expectancy of South Africans, to curb child and maternal mortality, to decrease the burden of HIV and tuberculosis and to increase the effectiveness of the healthcare system, as part of the Presidency's Medium Term Strategic Framework (Department of Health 2012a).

These policies build on the three streams of the re-engineering of the primary health care system: (1) district clinical specialist teams; (2) strengthening of school health services; and (3) ward based primary healthcare teams (Department of Health 2012b; Department of Health Ministerial Task Team 2012). Although physiotherapists are not an integral part of this team, they play a role in building capacity in these teams, which include community health workers. (World Health Organization 2006). The gap in the pro- vision of community health workers, a core member of the primary health care teams, is substantial (Department of Health 2011a). The implication of this under-provision is that other team members may have to step into areas of general competence needed by the team, such as epidemiological surveys, health promotion and prevention, palliative care, social mobilisation, linking resources with community needs, improvement of health outcomes and the celebration of team health days (Lehmann and Sanders 2007). In South Africa practitioners of traditional African medicine are also role players in providing health care (Health 2008a). Therefore, "a key professional competency is the ability to work with teams consisting largely of basic and ancillary health workers and supportive staff" (Frenk et al. 2010: 1 984). Another responsibility for health practitioners is therefore the transfer of skills to these cadres of workers (World Health Organization 2006; Department of Health 2011c).

Even in its guidelines for health establishments, the Department of Health emphasises public health (Department of Health 2011c). In this document "public health" is defined as follows:

"The Public Health domain" covers how health facilities should work with [non-governmental organisations] NGOs and other health care providers along with local communities and relevant sectors, to promote health, prevent illness and reduce further complications; and ensure that integrated and quality care is provided for their whole community, including during disasters" (Department of Health 2011b: 11).

Within the decentralised district health system, partnerships with community structures, such community-basedorganisations (CBOs), for mobilising community action and advocacy around health issues are, indeed, a recurrent theme (Department of Health 2004; 2005a; 2005b; 2007a). In addition, the Department of Health developed guidelines for the management of health services, including the use of technology in the delivery of healthcare services and mentorship (Department of Health 2011c; 2012c).

\section{Health profile of the South African population}

The health profile of the country is another driver of the curriculum (Kern et al. 2009). The quadruple burden of disease in SA (Groenewald et al. 2012) comprises (1) communicable, maternal and nutritional diseases; (2) HIV and tuberculosis (TB); (3) non-communicable diseases; and (4) injuries. The top ten risk factors of mortality directly relevant to physiotherapy are tobacco addition, lack of physical activity and hypertension and diabetes (as risk factors) (Groenewald et al. 2012). Other target groups that receive emphasis in the South African health policy environment are children, youth, women and people living with disability (Department of Health 2011a; 2012a; Health 2012b).

\section{Aim of the study}

The purpose of this article is to give an overview of education in community physiotherapy in South Africa - from study guides for community placements - as a guide for benchmarking by individual institutions. Another aim is to discuss how current health priorities discussed above, are reflected in these curricula.

\section{METHODS}

\section{Research setting and population}

SA has a three-tiered health system with healthcare services being rendered at primary, secondary and tertiary levels (Coovadia et al 2009), with some clinics and hospitals having additional outreach programmes. The training of health science students therefore needs to occur in different settings, including community-based organisations. In South Africa, eight city-based universities offer physiotherapy training as a four-year degree at Level 8 of the South African Qualifications Authority (SAQA): the University of the Cape Town, Free State, Kwa-Zulu Natal, Limpopo (Medunsa campus), Pretoria, Stellenbosch, Western Cape and Witwatersrand. Urban communitybased training is accessible, but rural and remote placements have significant logistical and especially cost implications. Programmes need to comply with 
the minimum standards set by both the relevant Quality Control Council's Standard Generating Bodies (SGBs) and the Health Professions Council of South Africa (HPCSA). All university departments that offered physiotherapy programmes were invited to participate in the study.

\section{Research design}

The research design for this study was a document analysis - a type of audit where documents are scoured to gain a clearer picture of a situation being investigated. The documents that were analysed were the SAQA Physiotherapy Qualifications document (2005) with institution's exit level outcomes and the study guides of community and/or physiotherapy placements (2008) at the identified training institutions.

\section{Data collection strategies}

The registered SAQA qualifications were downloaded from the National Qualifications Framework (NQF) website. To obtain the relevant study guides from the training institutions, an e-mail explaining the aim and procedure of this study was sent to the heads of the departments. Three types of documents were requested - the curriculum for community-based education; learning outcomes of syllabi preparing students for work in community and public health settings; and the learning outcomes for the placement(s) themselves. Follow-up e-mails were sent and telephone calls were made to the relevant individuals until at least one document had been received from each university.

\section{Ethical considerations}

The Ethics Committee of the Faculty of Health Sciences, University of Pretoria, approved the study (Ref 93/2008). Providing the requested documents implied informed consent to participate.

\section{DATA ANALYSIS PROCEDURES}

Qualitative content analysis was applied to manifest content of the texts (Graneheim and Lundman 2004). The unit of analysis was all the documents in each category (SAQA and study guides) from one university. Words, phrases, sentences or paragraphs "containing aspects related to each other through their content and context" (Graneheim and Lundman 2004: 106) were handled as meaning units for coding purposes. A first round of paper-based open coding was done. The list of codes were subsequently abstracted into categories and

Table 1. NQF sub field in which the qualifications were registered $(\mathrm{N}=8)$

\begin{tabular}{|l|l|}
\hline NQF Sub Field & Frequency \\
\hline Rehabilitative Health/Services & 3 \\
\hline Curative Health & 2 \\
\hline Promotive Health and Developmental Services & 1 \\
\hline Preventive Health & 1 \\
\hline Physical Sciences & 1 \\
\hline
\end{tabular}

linked into themes. A second round of coding was done using AtlasTi 6.2 software. Frequency counts were done in Microsoft Excel (Version 2003).

\section{RESULTS}

\section{Description of the sample}

The officially registered SAQA physiotherapy qualifications at the time of the study were used. Of these registered, seven were dated 2009 and one was dated 2006. Six universities submitted study guides, one submitted the syllabus of a module and one sent topics of a module.

\section{Document analysis of the SAQA programme registration docu- ments}

\section{National Qualification Framework (NRF) sub fields}

The sub fields selected by the physiotherapy university departments for registration of their qualifications $(n=8)$ are indicated in Table 1. The highest number of universities $(n=3)$ were registered in the field traditionally associated with the rehabilitation component of comprehensive healthcare, and two in curative health. Two selected a field in the preventative extreme of the comprehensive health care continuum, with one selecting a pure science sub field.

\section{SAQA exit level outcomes}

The main themes or competencies, which emerged from the analysis of the exit-level outcomes of the qualifications as registered with SAQA, are listed in the first columns of Table 2 and Table 3. The number of analysed meaning units

Table 2. The distribution of themes (competencies) of the SAQA exit-level outcomes for the registered undergraduate physiotherapy qualification by university $(\mathrm{N}=8)$

\begin{tabular}{|c|c|c|c|c|c|c|c|c|c|}
\hline \multirow[b]{2}{*}{ Theme (Competency) } & \multicolumn{8}{|c|}{$\begin{array}{l}\text { Number of coded meaning units } \\
\text { by University }\end{array}$} & \multirow[b]{2}{*}{$\begin{array}{l}\text { Total no. of } \\
\text { meaning units }\end{array}$} \\
\hline & 1 & 2 & 3 & 4 & 5 & 6 & 7 & 8 & \\
\hline Render a physiotherapy service & 1 & 2 & 10 & 4 & 3 & 4 & 8 & 2 & 34 \\
\hline Act professionally & 2 & 1 & 3 & 1 & 2 & 3 & 3 & 1 & 16 \\
\hline Communicate and collaborate & 1 & 1 & 4 & 2 & 2 & 1 & 1 & 1 & 13 \\
\hline Practice evidence based & - & 2 & 1 & 2 & 1 & 1 & 2 & 2 & 11 \\
\hline Totals & 4 & 6 & 18 & 9 & 8 & 9 & 14 & 6 & 74 \\
\hline
\end{tabular}


Table 3. Categories and themes (competencies) for the SAQA exit-levels outcomes for the registered undergraduate physiotherapy qualifications $(\mathrm{N}=8)$

\begin{tabular}{|l|l|}
\hline Theme competency & Categories \\
\hline Act professionally & $\begin{array}{l}\text { - Attributes: Caring, ethical, autonomous, socially responsive, flexible, innovative, life-long } \\
\text { learner and leader; critical and creative thinker and problem-solver } \\
\text { - Scope and realities of the profession and relevant laws and policies adhered to } \\
\text { - Self- and peer-review }\end{array}$ \\
\hline $\begin{array}{l}\text { Communicate and } \\
\text { Collaborate }\end{array}$ & $\begin{array}{l}\text { - Multidisciplinary team work } \\
\text { - Health education provision } \\
\text { - Written and verbal communication } \\
\text { - Client-centred approach }\end{array}$ \\
\hline $\begin{array}{l}\text { Render a physiotherapy } \\
\text { service }\end{array}$ & $\begin{array}{l}\text { - Community needs addressed } \\
\text { - Comprehensive services provided: preventive, promotive, curative and rehabilitative } \\
\text { - Families, groups, societies and the broader population served } \\
\text { - Staff developed } \\
\text { - Systems thinking }\end{array}$ \\
\hline Practice evidence based & - Scientific evidence appraised, used and developed \\
\hline
\end{tabular}

Table 4. Summary of the categories and themes in the outcomes for study guides $(\mathrm{N}=8)$

\begin{tabular}{|c|c|c|c|c|c|c|c|c|c|c|}
\hline \multirow[b]{2}{*}{ Theme } & \multirow[b]{2}{*}{ Category (Topics) } & \multicolumn{8}{|c|}{ University } & \multirow[b]{2}{*}{$\begin{array}{l}\text { No. of } \\
\text { universities }\end{array}$} \\
\hline & & 1 & 2 & 3 & 4 & 5 & 6 & 7 & 8 & \\
\hline \multirow{9}{*}{$\begin{array}{l}\text { Foundational } \\
\text { Principles }\end{array}$} & Determinants of health & & $x$ & $\mathrm{X}$ & $\mathrm{X}$ & $\mathrm{X}$ & $\mathrm{x}$ & & $x$ & 6 \\
\hline & Disability theory & $x$ & $x$ & $x$ & $\mathrm{X}$ & $x$ & $x$ & & & 6 \\
\hline & Social responsibility & $x$ & & $x$ & & & $x$ & & & 3 \\
\hline & The rehabilitation process & & & & $x$ & $x$ & & & $x$ & 3 \\
\hline & Asset-based approach & & $x$ & & $x$ & & & & & 2 \\
\hline & Bio-psychosocial model & & & & $x$ & & $x$ & & & 2 \\
\hline & Community development & & & $x$ & & $x$ & & & & 2 \\
\hline & Introduction to population health & & & $x$ & & & & & & 1 \\
\hline & Participatory models & & & & & $x$ & & & & 1 \\
\hline \multirow{5}{*}{$\begin{array}{l}\text { Health system and } \\
\text { policies }\end{array}$} & Health-care system/ District health & $\mathrm{X}$ & $\mathrm{x}$ & $x$ & & $\mathrm{x}$ & $\mathrm{x}$ & & & 5 \\
\hline & Levels of care & $\mathrm{x}$ & $\mathrm{X}$ & $x$ & $\mathrm{X}$ & & & & & 4 \\
\hline & Laws, acts, policies & $x$ & & $\mathrm{x}$ & $x$ & & & & & 3 \\
\hline & Welfare policy (e.g. grants) & & & & & $x$ & & & $x$ & 2 \\
\hline & Inter-sectoral collaboration & & & & & & & $\mathrm{X}$ & & 1 \\
\hline \multirow{3}{*}{$\begin{array}{l}\text { Health education } \\
\text { and promotion }\end{array}$} & Adult education skills/ Skills transfer & & & $x$ & $\mathrm{X}$ & $\mathrm{x}$ & & $\mathrm{X}$ & & 4 \\
\hline & Health education & $\mathrm{x}$ & $\mathrm{x}$ & $\mathrm{X}$ & & $\mathrm{x}$ & & & & 4 \\
\hline & Screening & & $\mathrm{x}$ & & & $\mathrm{x}$ & & & $\mathrm{X}$ & 3 \\
\hline \multirow[t]{5}{*}{ Management } & Evaluation & & $\mathrm{x}$ & $x$ & & $x$ & & $x$ & & 4 \\
\hline & Assess the environment & & $\mathrm{x}$ & $\mathrm{x}$ & & & & & & 2 \\
\hline & $\begin{array}{l}\text { Planning and organising programmes } \\
\text { and projects }\end{array}$ & & & $\mathrm{x}$ & & & & & $x$ & 2 \\
\hline & Outcome measures in public health & & & & & $x$ & & & $x$ & 2 \\
\hline & Information technology & & & & & & $\mathrm{X}$ & & & 1 \\
\hline
\end{tabular}

Not included: Reflection, Communication skills, Group dynamics, Time management, Cultural and gender sensitivity, Ethical and Professional conduct and interdisciplinary collaboration 
Table 5. Distribution of setting and the themes (teaching-learning setting and type of target group) by category specified in community/public health study guides, by university $(\mathrm{N}=8)$

\begin{tabular}{|c|c|c|c|c|c|c|c|c|c|c|c|}
\hline \multirow[b]{2}{*}{ Theme } & \multirow{2}{*}{\multicolumn{2}{|c|}{ Category }} & \multicolumn{8}{|c|}{ University Physiotherapy Department } & \multirow[b]{2}{*}{ Frequency } \\
\hline & & & 1 & 2 & 3 & 4 & 5 & 6 & 7 & 8 & \\
\hline \multirow[t]{7}{*}{ Settings } & \multicolumn{2}{|c|}{ Community settings } & & & & & & & & & \\
\hline & - & Homes of clients & $\mathrm{X}$ & $x$ & $\mathrm{x}$ & & & & & & 3 \\
\hline & - & Schools & $\mathrm{X}$ & & $\mathrm{x}$ & & & & & $x$ & 3 \\
\hline & - & Workplace/Factories & $\mathrm{X}$ & & $\mathrm{x}$ & & & & & $\mathrm{x}$ & 3 \\
\hline & - & Clinics & $\mathrm{X}$ & & $\mathrm{x}$ & & & & & & 2 \\
\hline & - & Homes for the elderly & $x$ & & $\mathrm{x}$ & & & & & & 2 \\
\hline & - & Rural/Urban & $\mathrm{X}$ & & $x$ & & & & & & 2 \\
\hline \multirow{9}{*}{$\begin{array}{l}\text { Target } \\
\text { groups }\end{array}$} & \multicolumn{2}{|c|}{ Clients with } & & & & & & & & & \\
\hline & - & Older age & & & $x$ & & $x$ & & $x$ & $x$ & 4 \\
\hline & - & Disability & $x$ & & & & & & $x$ & & 2 \\
\hline & - & Disability, Sport & $x$ & & & & & & & & 1 \\
\hline & - & Hypertension & $x$ & & & & & & & & 1 \\
\hline & - & Mental illness & & & & & $\mathrm{X}$ & & & & 1 \\
\hline & - & Tuberculosis & $x$ & & & & & & & & 1 \\
\hline & - & HIV & $x$ & & & & & & & & 1 \\
\hline & Total & & 11 & 1 & 7 & 0 & 2 & 0 & 2 & 3 & \\
\hline
\end{tabular}

Table 6. Types of teaching-learning strategies by university $(\mathrm{N}=8)$

\begin{tabular}{|c|c|}
\hline University & Learning strategy \\
\hline 1 & $\begin{array}{l}\text { Spend } 8 \mathrm{~h} \text { with a person with disabilities (minimum of three to four visits) } \\
\text { Service learning block at community health centre and old age homes (Three days clinical block per } \\
\text { student group of three to four students) }\end{array}$ \\
\hline 2 & $\begin{array}{l}\text { Case report of a client at home, Health talk, Screening of children/babies and addressing problems, } \\
\text { portfolio }\end{array}$ \\
\hline 3 & Small group discussions, Home visits, Service learning projects \\
\hline 4 & $\begin{array}{l}\text { Lectures, Small group discussions, Problem-based learning using simple paper cases, } \\
\text { Projects during field trips }\end{array}$ \\
\hline 5 & Not explicit \\
\hline 6 & Not explicit \\
\hline 7 & Lectures, Group-work, Presentations, Site visits \\
\hline 8 & $\begin{array}{l}\text { Home visits, Factory visit, Personal strength, weakness, opportunity and threat analysis, Screening for } \\
\text { participation in group classes, Information session, Service learning projects, Portfolio } \\
\text { Facilitation session } \\
\text { About time management in different community areas } \\
\text { Ethical issues around disability grants }\end{array}$ \\
\hline
\end{tabular}

that contributed to each theme is given in columns according to university, with the total number of meaning units supporting each theme or competency in the last column of Table 2. The categories that made up each theme are listed in the second column of Table 2 .
Document analysis of study guides of community placements

A summary of the findings from the study guides are presented in Table 4-6. Table 4 highlights the categories and themes according to university with the summed totals. In table 5, the teaching and learning settings and type of patients (by age group and condition) treated by students that were explicitly mentioned in the study guides are summarised. Table 6 lists the teaching and learning strategies employed at each university. 


\section{DISCUSSION}

Findings from this study give an overview of education in community physiotherapy in South Africa in terms of topics dealt with in the undergraduate community physiotherapy curricula and teaching-learning strategies followed to develop five exit level competencies: to deliver a physiotherapy service, to act professionally, to collaborate, communicate and to practice according to scientific evidence. Four themes emerged from study guides namely foundational topics, such as the determinants of health; the health system - specifically district health - and policies; health education and promotion, and the management of physiotherapy services.

\section{National Qualifications Framework (NQF) sub fields}

Programmes were registered in five different fields of the NQF. The NQF sub field that each institution selected for registration of the respective qualifications may signify the underlying philosophy of each course. Only two institutions selected a field in the preventative extreme of the comprehensive health care continuum. This continuum stretches from health protection and health promotion at one end, to cure, as well as rehabilitation and palliative care, at the other. As physiotherapy's scope covers the full spectrum of com- prehensive health care and in light of the quadruple burden of disease in SA, the finding shows the difference in focus of universities while complying with the core prescriptions of the HPCSA (2003).

\section{Exit-level and community block outcomes}

The topics under the theme "foundational principles" are related to the philosophy and perspectives that guide physiotherapy interventions. For example, not only are interventions that address disablement (impairments, activity and participation limitations) important (e.g. "the rehabilitation process,"), but also attending to the factors that cause dysfunction in the first place ("determinants of health," "biopsychosocial model"). Having a preventative stance implies moving beyond the individual patient to integration back into the community which they form a part of ("Public Health"). The themes in this topic imply attention to physiotherapist and community strengths and facilitators ("assetbased approach"). The topics also speak to the fact that physiotherapy is not only about disease, but also about uplifting communities ("community development"), working with clients and not for them ("participatory models") and tackling inequities in the service ("social responsibility") and human right issues (“disability theory").
Secondly, the theme "health system and policies" dealt with understanding the healthcare system ("levels of care," "inter-sectoral collaboration)" and the policies and acts guiding practice ("laws, policies," and "welfare policy"). Skills to educate patients about their health ("adult education skills/skills transfer, "health education" and identifying risk factors ("screening") were dealt with under the theme "health education and promotion". Finally, the theme "management" addressed the issue of strategically providing and organising physiotherapy services ("assess the environment," "planning and organising programmes and projects") and measuring their effect at population level ("outcome measures in public health"). The "management" theme also dealt with the use of information technology when providing services.

In the SAQA qualification documents of the universities the cross-field outcomes therefore received much attention. These are general competencies to prepare students for the challenges of the work environment, such as being able to work in teams and to be able to communicate - important themes in current curriculum frameworks (Shilton et al. 2008; Therapy Project 2008; Barry et al. 2009; Lin et al. 2009; Verma et al. 2009; National Physiotherapy Advice Committee 2010; Grace and Trede 2011;

Table 7. Summary of roles and attributes for medical doctors/physiotherapists internationally

\begin{tabular}{|c|c|c|c|c|c|c|}
\hline $\begin{array}{l}\text { Boelen }^{\mathrm{a}} \\
\text { [c. 1996] }\end{array}$ & $\begin{array}{l}\text { CanMEDS } \\
(2005)\end{array}$ & GMC (2009)c & Frenk et al.(2010) ${ }^{d}$ & CSPe & WCPT (2012) & RSA $(2009)^{f}$ \\
\hline $\begin{array}{l}\text { - Care provider } \\
\text { - Communicator } \\
\text { - Community } \\
\text { leader } \\
\text { - Decision-maker } \\
\text { - Manager }\end{array}$ & $\begin{array}{l}\text { - Medical expert } \\
\text { - Communicator } \\
\text { - Collaborator } \\
\text { - Health } \\
\text { Advocate } \\
\text { - Professional } \\
\text { - Scholar } \\
\text { - Manager }\end{array}$ & $\begin{array}{l}\text { - Practitioner } \\
\text { - Professional } \\
\text { - Scholar and } \\
\text { scientist }\end{array}$ & $\begin{array}{l}\text { - Expert } \\
\text { (Information Skills) } \\
\text { - Professional } \\
\text { (Socialisation, } \\
\text { values) } \\
\text { - Change agent } \\
\text { (leadership } \\
\text { attributes) }\end{array}$ & $\begin{array}{l}\text { - Putting patient/ } \\
\text { population } \\
\text { needs at the } \\
\text { centre } \\
\text { - Supporting } \\
\text { - Educating } \\
\text { - Leading } \\
\text { - Managing } \\
\text { - Researching }\end{array}$ & $\begin{array}{l}\text {-Public health strategies } \\
\text { - Supervising and } \\
\text { delegating to others } \\
\text { - Leading } \\
\text { - Managing } \\
\text { - Teaching } \\
\text { - Developing and } \\
\text { implementing health } \\
\text { policy, } \\
\text { - Research } \\
\text { - Advocating for } \\
\text { patients/clients and } \\
\text { for health }\end{array}$ & $\begin{array}{l}\text { - Clinical practitioner } \\
\text { - Understand foundational } \\
\text { principles } \\
\text { - Render a physiotherapy } \\
\text { service } \\
\text { - Work within the health } \\
\text { system and policies } \\
\text { - Communicate and } \\
\text { collaborate } \\
\text { - Manage } \\
\text { - Act professionally } \\
\text { - Practice evidence-based } \\
\text { physiotherapy - } \\
\text { - Manage }\end{array}$ \\
\hline
\end{tabular}

${ }^{a}$ Five-star doctor; ${ }^{\mathrm{c}}$ Tomorrow's doctor ${ }^{\mathrm{d}}$ Chartered Society for Physiotherapy: Outcomes and objectives of education; ${ }^{\mathrm{e}}$ Generic behaviours;

${ }^{\mathrm{f}}$ Clinical functions were not specifically coded 
Maeshiro et al. 2011; Basu and Roberts 2012; Pellegrino and Hilton 2012; Voogt and Roblin 2012).

Although the professional physiotherapy-specific competencies cannot be overemphasised, the study shows that physiotherapy educators have embraced the notion of educating well-rounded reflective professionals. The competency outcomes found in this study encompass the roles, outcomes, domains and behaviours identified by organisations internationally (See Table 7).

For example, attention had already been drawn in the Flexner report of 1910 to the fact that medical doctors need to be more than clinicians to make an impact on health care in societies (Flexner 1990). In response to the multi-faceted nature of healthcare the World Health Organization (WHO) formulated five roles for the medical doctor (World Health Organization 1996: 08). These roles were care provider, communicator, community leader, decision maker and manager.

Table 7 gives a summary of the further development of similar roles. The CanMEDS model (Frank and Danoff 2007) made the health advocacy role (previously included in the communicator role) and that of a professional and scholar explicit. The UK General Medical Council (United Kingdom) (2009) and Frenk et al. (2010) each simplified the roles to three, with the last of the three emphasising the role as change agent. The Chartered Society of Physiotherapy (c.2012) in turn determined the objectives of education of physiotherapy undergraduates and the World Confederation for Physical Therapy (World Confederation for Physical Therapy 2011) generic behaviours. An essential competency as part of the communicator role is that of cultural competency, especially if the diversity in the student and client profiles is taken into account (Das 2005).

Similar themes can be found in curricula from Canada (University of British Colombia Department of Physiotherapy n.d.), Nigeria (Medical Rehabilitation Therapists (Registration) Board of Nigeria n.d.), and Ethiopia (Gondor University Department of Physiotherapy n.d.).
Alignment with the policy environment and health profile of the South African population

Almost all of the universities indicated that they address the social determinants of health, the district health system and health education in their curricula. These themes are aligned with the country's vision to alleviate poverty and improve the life-expectancy of its people (Department of Health 2002; 2004; The Presidency RSA 2008; Department of Health 2009; The Presidency RSA 2010; Department of Health 2012c). A focus on health education and health promotion is the case in physiotherapy education in both developed and developing countries. For example, in the UK health promotion and the theme of 'staying healthy' are embedded in the final year of the curriculum (Chartered Society of Physiotherapy c.2012). Within this theme, students learn how to safely prescribe, implement and monitor physical activity programmes in order to address obesity, to help prevent ill health and falls in the elderly, and to improve the health of people with learning disabilities and mental health issues.

Equally well-presented in South African outcomes is the evaluation of programmes which links with improved effectiveness of the the health care system (Department of Health 2007). However, the level of attention that three streams of re-engineered primary health care receive is not clear (Department of Health 2008a; 2012d; Department of Health Ministerial Task Team 2012). One may be skeptical as no-one explicitly referred to work with mid-level workers, volunteers and practitioners of traditional African medicine. As only one university indicated schools as a setting of education, it appears as if school health has not been embraced. The rest of the themes, such as community development and social responsibility, were explicitly addressed by less than half of the universities. Another apparent neglected field is that of e-Health (Department of Health 2012e)

Physiotherapists are skilled to address the quadruple burden of disease in the RSA, however, priority conditions have been mentioned explicitly only in the minority of the education institutions.
Paradoxically to the Government's focus on child and youth health (The Presidency Rsa 2009; The Presidency Rsa and The United Nations Children's Fund 2009; Department of Health 2012a; 2012d), the majority of study guides were explicit about services to older clients.

All the settings were outside of hospitals, like at clients' homes, industry and community institutions (homes for the elderly). Less than half of the institutions specified home visits as a learning opportunity during the community/ public health placement.

\section{TEACHING-LEARNING STRATEGIES}

\section{Learning opportunities}

Those universities whose documents included learning strategies tend to use authentic problem-orientated stimuli to facilitate learning, ranging from papercases to treatment of real patients during home-visits (Donaghy and Morss 2007; Bowe et al 2009). Experiential learning, with site visits, projects such as screening, field work and service learning, was common. These approaches are fundamental components for developing complex competencies, such as those indicated in the learning outcomes (Frantz and Rhoda 2007; Rodger et al. 2008; Adam et al 2013).

Educators, indeed, endorse service learning for teaching complicated ideas such as the social determinants of health and to develop civic-minded graduates (Hatcher and Erasmus 2008; Hunt, Bonham and Jones 2011). The andragogy has been useful in teaching preventative medicine, promoting wellness and public health (Buckner et al. 2010; Chastonay et al. 2012). The reciprocal relationship between learning and service benefits the clients through increased access to health care (Jimenez et al. 2008).

Service-learning is defined as a "course-based, credit bearing educational experience in which students (a) participate in an organized service activity that meets identified community needs, and (b) reflect on the service activity in such a way as to gain further understanding of course content, a broader appreciation of the discipline, 
and an enhanced sense of personal values and civic responsibility." (Bringle and Hatcher 2009:38).

Examples of reflexive activities utilised in these South African universities are assignments like presentations, individual reflection on one's own strengths and weaknesses, reflection in small groups and discussions about ethical issues (Eyler 2002). A portfolio (used by two institutions) is particularly useful, when combined with feedback, to demonstrate professional development (Mori, Batty and Brooks 2008; Buckley et al. 2009).

\section{LIMITATIONS OF THE RESEARCH}

A limitation of the study is that the study guides were used as a proxy for the full curriculum and were possibly not a true representation of the curriculum. The findings are not a comprehensive view of the universities' education standards in terms of community and public health physiotherapy, as no university's full curriculum was available for the document analysis. One reason may be that the timing of the request was not quite convenient, as people were scaling down at the end of the academic year. Also exit-level competencies are broadly stated and do not reflect detailed elements, such as the type of healthcare workers seen as part of the health care team.

Findings from the study-guide document analysis must therefore be interpreted with caution, as the documents that were analysed provided only a snapshot of the curriculum. Outcomes not listed by certain universities may well be covered in other blocks or modules. Clinical competencies were also excluded from the document analysis.

The document analysis included only documents from the final two years of the four-year degrees. However, a systematic review of clinical- and community-based education of medical students found that early exposure - within the first two years of study - had a range of benefits similar to Futter's (2003) findings (Dornan et al. 2006). These benefits included improved motivation, professional development, confidence and communication when interacting with patients, as well as clinical skills.
Students better understood the structure and function of the healthcare system and the role of preventative care.

\section{IMPLICATIONS FOR PRACTICE}

Despite progress towards communitybased education, each of the universities has gaps in their community/public health curricula that need to be reviewed against the health policies and priorities in the country. The special interest group for public health of the South African Society of Physiotherapy (SASP) has been slow to come off the ground. Academics need to drive this initiative. Forming a virtual community of practice using a social media platform like Google groups may be a viable option. Resources, such as case studies, can be shared via this platform. Due to the interdisciplinary nature of public health, linking with multidisciplinary groups, such as the recently launched Rural Rehab South Africa (RuRaSa) (www. ruralrehab.co.za/ ) is recommended.

Recently qualified physiotherapists are a rich source of information about the realities of community service in South Africa that should be tapped. Incorporating these physiotherapists' experiences of community physiotherapy would further contribute to authentic educational experiences. For example, they need to develop resiliency during their studies to deal with sub optimal practice environments in the public sector (Mostert-Wentzel, Frantz and van Rooijen 2013). A Delphi study with clinicians, managers and academics identified that the clinician role stays central even in community work. Professionalism, communication and collaboration, inquiry-led practice, clinical prevention and health promotion, population health and management and leadership are essential complementary elements in community physiotherapy (Mostert-Wentzel 2013).

\section{REFERENCES}

Adam, K., Strong, J. \& Chipchase, L. 2013. Preparing occupational therapy and physiotherapy students for work-related practice: A clinical education initiative at one Australian university. The Internet Journal of Allied Health Sciences and Practice,11(1),1-9.http://0-ijahsp.nova.edu.innopac. up.ac.za/articles/Vol11 Num1/pdf/Adam.pdf

Barry, M.M., Allegrante, J.P., Lamarre, M., Auld, M.E. \& Taub, A. 2009. The Galway Consensus conference: International collaboration on the development of core competencies for health promotion and health education. Global Health Promotion, 16(2),5-11.

Basu, S. \& Roberts, C. 2012. Towards a public health curriculum in undergraduate medicine. Education for Health, 25(2),98-104.

Bowe, C.M.A., Voss, J. \& Thomas Aretz, H. 2009. Case method teaching: An effective approach to integrate the basic and clinical sciences in the preclinical medical curriculum. Medical Teacher, 31(9),834-41.

Bringle, R.G. \& Hatcher, J.A. 2009. Innovative practices in service-learning and curricular engagement. New Directions for Higher Education, 2009(147),37-46.

Broberg, C., Aars, M., Beckmann, K., Emaus, N., Lehto, P., Lähteenmäki, M., et al. 2003. A conceptual framework for curriculum design in physiotherapy education: An international perspective. Advances in Physiotherapy, 5(4),161-68.

Buckley, S., Coleman, J., Davison, I., Khan, K.S., Zamora, J., Malick, S., et al. 2009. The educational effects of portfolios on undergraduate student learning: A Best Evidence Medical Education (BEME) systematic review. BEME Guide No. 11. Medical Teacher, 31(4),282-98.

Buckner, A.V., Ndjakani, Y.D., Banks, B. \& Blumenthal, D.S. 2010. Using service-learning to teach community health: The Morehouse School of Medicine Community Health course. Academic Medicine, 85(10),1 645-51

Burch, V.C. 2007. Medical education in South Africa: Assessment practices in a developing country. Chap. 2. [thesis]. Rotterdam: Erasmus University, [cited 2012 June 19] Available from:<http://repub.eur.nl/res/pub/10152/>

Cashman, S.B. \& Seifer, S.D. 2008. Servicelearning: An integral part of undergraduate public health. American Journal of Preventive Medicine, 35(3), 273-78. 
Chartered Society of Physiotherapy c.2012. Physiotherapy framework. London: Chartered Society of Physiotherapy

Chastonay, P., Vu, N.V., Humair, J.P., Mpinga, E.K. \& Bernheim, L. 2012. Design, implementation and evaluation of a community health training program in an integrated problem-based medical curriculum: A fifteen-year experience at the University of Geneva Faculty of Medicine. Medical Education Online, 17(http://0-www. ncbi.nlm.nih.gov.innopac.up.ac.za/pmc/articles/ PMC3387672/pdf/MEO-17-16741.pdf

Coovadia, H., Jewkes, R., Barron, P., Sanders, D. \& McIntyre, D. 2009. The health and health system of South Africa: Historical roots of current public health challenges. The Lancet, 374(9692),817-34.

Darrah, J., Loomis, J., Manns, P., Norton, B. \& May, L. 2006. Role of conceptual models in a physical therapy curriculum: Application of an integrated model of theory, research, and clinical practice. Physiotherapy Theory and Practice, 22(5),239-50

Das, R. 2005. Internationalisation of the curriculum: Putting theory into practice in a physiotherapy program. Journal of University Teaching and Learning Practice, 2(1),3 screens.

Davenport, N.C., Spath, M.L. \& Blauvelt, M.J. 2009. A step-by-step approach to curriculum review. Nurse educator, 34(4),181-85.

Democracy and Governance Human Science Research Council (HSRC) 2005. Overcoming the legacy of discrimination in South Africa: Report to the Presidency, South Africa. Pretoria, RSA: The Presidency

Department of Health 2002. District hospital package: A set of norms and standard. Pretoria, RSA: Department of Health

Department of Health 2004. Transformation of the health care system: Decentralise to district level. Pretoria, RSA: Department of Health

Department of Health 2005a. National guideline on home-based care/community-based care. Pretoria, South Africa: Department of Health

Department of Health 2005b. Service package guidelines for home and community-based care and support and the role of community care workers. Pretoria, RSA: Department of Health

Department of Health. 2007. Quality in health care. Pretoria, South Africa: Department of Health

Department of Health 2008a. The Birchwood national consultative health forum declaration on primary health care. Recommitment to primary health care (PHC). Pretoria, RSA: Department of Health

Department of Health 2008b. Draft national policy on African traditional medicine in South Africa. Pretoria, South Africa: Department of Health

Department of Health 2009. Government's Programme of Action 2009 Human Development Cluster: Health. Pretoria, South Africa: Department of Health

Department of Health 2011a. National strategic plan on HIV, STDs and TB 2012-2016. Pretoria, RSA: Department of Health.

Department of Health. 2011b. Human resources for health in South Africa: HRH Strategy for the health sector: 2012/13 - 2016/17. Pretoria, RSA: Department of Health

Department of Health 2011c. National core standards for health establishments in South Africa: Towards quality care for patients. Pretoria, RSA: National Department of Health

Department of Health 2011d. Clinical mentorship manual for integrated services. Pretoria, RSA: National Department of Health

Department of Health 2012a. Strategic plan for maternal, newborn, child and women's health (MNCWH) and nutrition in South Africa: $2012-$ 2016. Pretoria, RSA: Department of Health

Department of Health 2012b. South Africa's national strategic plan for a campaign on accelerated reduction of maternal and child mortality in Africa (CARMMA). "South Africa cares: No woman should die while giving life". Pretoria, RSA: Department of Health

Department of Health 2012c. The aid effectiveness framework for health in South Africa: Working together to implement the Negotiated Service Delivery Agreement and to attain the Millennium Development Goals. Pretoria, RSA: Department of Health

Department of Health 2012d. Integrated school health policy. Pretoria, RSA: Department of Health

Department of Health 2012e. eHealth strategy South Africa: 2012-2016. A long and healthy life for all South Africans. Pretoria, RSA: Department of Health

Department of Health Ministerial Task Team 2012. District clinical specialist teams in South Africa: Ministerial task team report to the honourable Minister of Health Dr Aaron Motsoaledi. Pretoria, RSA: Department of Health
Donaghy, M. \& Morss, K. 2007. An evaluation of a framework for facilitating and assessing physiotherapy students' reflection on practice. Physiotherapy Theory \& Practice, 23(2),83-94.

Dornan, T., Littlewood, S., Margolis, S.A., Scherpbier, A., Spencer, J. \& Ypinazar, V. 2006. How can experience in clinical and community settings contribute to early medical education? A BEME systematic review. Medical Teacher, 28(1),3-18.

Eyler, J. 2002. Reflecting on service: Helping nursing students get the most from service-learning. Journal of Nursing Education, 41(10),453-6.

Flexner, A. 1990. Medical education in the United States and Canada. Birmingham, Ala.: Classics of Medicine Library

Frank, J.R. \& Danoff, D. 2007. The CanMEDS initiative: Implementing an outcomes-based framework of physician competencies. Medical Teacher, 29(7),642-47.

Frantz, J. \& Rhoda, A. 2007. Assessing clinical placements in a B.Sc. physiotherapy program. The Internet Journal of Allied Health Sciences and Practice, 5(3), http://0-ijahsp.nova.edu. innopac.up.ac.za/articles/vol5num3/frantz. pdf?referer=www.clickfind.com.au

Frenk, J., Chen, L., Bhutta, Z.A., Cohen, J., Crisp, N., Evans, T., et al. 2010. Health professionals for a new century: Transforming education to strengthen health systems in an interdependent world. The Lancet, 376(9756),1923-958.

Futter, M.J. 2003. Developing a curriculum module to prepare students for community-based physiotherapy rehabilitation in South Africa. Physiotherapy, 89(1),13-24.

General Medical Council (United Kingdom) 2009. Tomorrow's doctors. London: GMC

Gondor University Department of Physiotherapy n.d. Physiotherapy curriculum [Internet]. Ethiopia: Gondor University. [cited 2012 Nov 15] Available from: http://www.wcpt.org/node/33154

Grace, S. \& Trede, F. 2011. Developing professionalism in physiotherapy and dietetics students in professional entry courses. Studies in Higher Education, [10.1080/03075079.2011.603410]

Graneheim, U.H. \& Lundman, B. 2004. Qualitative content analysis in nursing research: concepts, procedures and measures to achieve trustworthiness. Nurse Education Today, 24(2), 105-12. 
Groenewald, P., Msemburi, W., Neethling, J., Day, C., Tuoane-Nkhazi, M. \& Bradshaw, D. 2012. District Health Barometer 2010/11. Pretoria, South Africa: South African Medical Research Council, Health Systems Trust and Statistics South Africa

Hatcher, J.A. \& Erasmus, M.A. 2008. Servicelearning in the United States and South Africa: A comparative analysis informed by John Dewey and Julius Nyerere Michigan Journal of Community Service Learning, 5(1),49-61.

Health Professions Council of South Africa 2003. Professional Board for Physiotherapy, Podiatry and Biokinetics. Minimum standards for the training of physiotherapy students. Form 96. http://www.hpcsa.co.za/hpcsa/UserFiles/File/ F96PhysMinStandards.doc

Hunt, J.B., Bonham, C. \& Jones, L. 2011. Understanding the goals of service learning and community-based medical education: A systematic review. Academic Medicine, 86(2),246-51

Jimenez, M., Tan-Billet, J., Babineau, J., Jimenez, J.E., Billet, T., Flash, C., et al. 2008. The promise clinic: A service learning approach to increasing access to health care. Journal of Health Care for the Poor and Underserved, 19(3),935-43.

Kern, D.E., Thomas, P.A. \& Hughes, M.T. 2009. Curriculum development for medical education: A six-step approach. Baltimore, Md.: Johns Hopkins University Press

Krause, M.W. 2007. Service learning in physiotherapy taken to a new level: Experiences in South Africa. Physical Therapy Reviews, 12(4),277-84.

Lehmann, U. \& Sanders, D. 2007. Community health workers: What do we know about them? [Internet]. [cited 2011 Nov 11] Available from: http://0-www.who.int.innopac.up.ac.za/hrh/ documents/community_health_workers.pdf

Lin, I.B., Beattie, N., Spitz, S. \& Ellis, A. 2009. Developing competencies for remote and rural senior allied health professionals in Western Australia. Rural And Remote Health, 9(2),1 115. [doi:http://www.rrh.org.au]

Maeshiro, R., Evans, C.H., Stanley, J.M., Meyer, S.M., Spolsky, V.W., Shannon, S.C., et al. 2011. Using the Clinical Prevention and Population Health Curriculum Framework to encourage curricular change. American Journal of Preventive Medicine, 40(2),232-44.

Medical Rehabilitation Therapists (Registration) Board of Nigeria n.d. Harmonised curriculum of studies for the Bachelor of Physiotherapy (B.PT.) degree programme in Nigerian universities as a standard control measure. [Internet]. [cited 2011 Nov 11] Available from: http://www.wcpt.org/ node/33154

Mori, B., Batty, H.P. \& Brooks, D. 2008. The feasibility of an electronic reflective practice exercise among physiotherapy students. Medical Teacher, 30(8),e232-e38.

National Physiotherapy Advice Committee 2010. Essential competency profile for physical rehabilitation therapists in Québec. [Ordre professionnel de la physiothérapie du Québec] [Internet]. [cited 10 July 2012] Available from: $<$ http://oppq.qc.ca/centre-documentation/?s=Com petency+profile.>

Nokes, K.M., Nickitas, D.M., Keida, R. \& Neville, S. 2005. Does service-learning increase cultural competency, critical thinking, and civic engagement? Journal of Nursing Education, 44(2),65-70.

Pellegrino, J.W. \& Hilton, M.L. 2012. Education for life and work: Developing transferable knowledge and skills in the 21st century. Washington, DC: National Research Council

Ramklass, S.S. 2009a. Physiotherapists in underresourced South African communities reflect on practice. Health and Social Care in the Community, 17(5),522-9.

Ramklass, S.S. 2009b. An investigation into the alignment of a South African physiotherapy curriculum and the expectations of the healthcare system. Physiotherapy, 95(3),216-23.

Rodger, S.A., Webb, G., Devitt, L., Gilbert, J., Wrightson, P. \& McMeeken, J. 2008. Clinical education and practice placements in the allied health professions: An international perspective. Journal of Allied Health, 37(1),53-62.

Shilton, T., Howat, P., James, R., Burke, L., Hutchins, C. \& Woodman, R. 2008. Health promotion competencies for Australia 2001-5: Trends and their implications. Promotion and Education, 15(2),21-26.

Stainsby, K. \& Bannigan, K. 2011. Reviewing work-based learning opportunities in the community for physiotherapy students: An action research study. Journal of Further and Higher Education, 36(4), 1-18.

The Presidency RSA 2008. Towards and antipoverty strategy for South Africa: A discussion document. Pretoria, RSA: The Presidency

The Presidency RSA 2009. National youth policy 2009 to 2014 [Internet]. [cited 2013 Feb 02] Available from: http://www.thepresidency.gov.za/
MediaLib/Downloads/Home/Publications/ YouthPublications/NationalYouthPolicyPDF/ NYP.pdf

The Presidency RSA 2010. Social cohesion and social justice in South Africa. Pretoria, RSA: The Presidency

The Presidency RSA \& the United Nations Children's Fund 2009. Situation analysis of children in South Africa. Pretoria, RSA: The Presidency

The Presidency: National Planning Commission. 2010. Development indicators. Pretoria, RSA: National Planning Commission, NPC.

Therapy Project Office 2008. Physiotherapy competencies, Ireland: National Implementation Group for clinical placement for Ocupational Therapy, Physiotherapy, and Speech and Language Therapy.

Thurgood, M. 2009. Chronic pain: A communitybased exercise and education program [thesis]. Kingston, Ontario, Canada: Queens University [cited on 2012 Nov 7] Available from: <http://0hdl.handle.net.innopac.up.ac.za/1974/5176>

University of British Colombia Department of Physiotherapy n.d. Physiotherapy curriculum [Internet]. [cited 2011 Nov 7] Available from: http://www.wcpt.org/node/33154

Verma, S., Broers, T., Paterson, M., Schroder, C., Medves, J.M. \& Morrison, C. 2009. Core competencies: The next generation. Comparison of a common framework for multiple professions. Journal of Allied Health, 38(1),47-53.

Voogt, J. \& Roblin, N.P. 2012. 21st century skills: A discussion paper. Enschede, the Netherlands: University of Twente

World Confederation for Physical Therapy 2011. Policy statement: Education. London, UK: WCPT

World Health Organization 1996. Doctors for health: A WHO global strategy for changing medical education and medical practice for health for all. Geneva: WHO

World Health Organization 2006. The World Health report 2006: Working together for health. Geneva: World Health Organization http://0-www. who.int.innopac.up.ac.za/whr/2006/en/ 